\title{
Changes in physical and hydraulic properties of a clay soil due to the irrigation of tomatoes with recycled wastewater
}

\author{
Azize DOĞAN DEMIRR ${ }^{1 *}$, Üstün ŞAHİN ${ }^{2}$ \\ ${ }^{1 *}$ Department of Biosystem Engineering, Faculty of Agriculture, Bingöl University, Bingöl, Turkey \\ ${ }^{2}$ Department of Agricultural Structures and Irrigation, Faculty of Agriculture, Atatürk University, Erzurum, \\ Turkey \\ Corresponding author: ademir@bingol.edu.tr
}

\begin{abstract}
This study was carried out investigate the effect of treated wastewater on the physical, chemical and hydraulic properties of the soil in Bingöl conditions during 2013 and 2014 years. In this study physical (bulk density, particle density, porosity, wet aggregate stability) and hydraulic properties (field capacity, wilting point, available water content, infiltration) of the soil did not change significantly under different irrigation practices. However, the porosity, available water content, and infiltration improved partly under partial root-zone drying practice with $50 \%$ water shortage. Wet aggregate stability in surface soil increased significantly with wastewater treatment. Wastewater reduced the stable infiltration rate significantly as well. Although the physical and hydraulic properties improved when compared with the pre-planting values, the wastewater treatment could not provide sustainable important effects in a short-time period.
\end{abstract}

Key words: Municipal wastewater, Soil properties, Irrigation practices

\section{Introduction}

Nowadays, wastewater treatment and reuse for agriculture in arid and semi-arid regions is an important factor in saving water resources. Physical and hydraulic properties of the soils irrigated with wastewater can be affected positively due to high organic matter content in the wastewater. The high organic matter is the main component in the improvement of soil aggregation (Nadav et al. 2013). The water retention capacity and hydraulic conductivity of the soil can be increased due to better soil aggregation.

An increase of sodicity level in the soil leads to deterioration of the porosity, bulk density, water retention, and infiltration rate. However, structural deterioration depends on the interaction between sodicity and electrolyte concentration of the soil solution (Muyen et al., 2011). Many research results reported generally negative effects on the soil properties under the wastewater irrigation conditions. Assouline et al. (2016) pointed out an increasing sodicity hazard and a decreasing hydraulic conductivity in the treated wastewater irrigation. Schacht and Marschner (2015) found lower soil hydraulic conductivity and aggregate stability values under the treated wastewater application. Assouline and Narkis (2011) reported that long-term wastewater irrigation adversely affected soil hydraulic properties. Aiello et al. (2007) indicated lower soil porosity in the wastewater application and a consequent decrease in water retention and hydraulic conductivity.

In this study, our aim is to investigate the effect of wastewater on the physical and hydraulic properties of soil in tomato plants irrigated with wastewater. 


\section{Material and methods}

The mean elevation of the study area from sea level was $1030 \mathrm{~m}$ and the study area is located at latitude $38^{\circ} 53^{\prime} 01,91^{\prime \prime}-38^{\circ} 53^{\prime} 01,52^{\prime \prime} \mathrm{N}$ and longitude $40^{\circ} 32^{\prime} 57,82^{\prime \prime}-40^{\circ} 32^{\prime} 56,73^{\prime \prime} \mathrm{E}$. The region has a continental climate (Dsa; D: cold continental climate, s: dry summer, a: hot summer), with hot and dry summers and cold and snowy winters considering Köppen classification (Kottek et al., 2006).

Table 1 shows the long-term average climatic data and climatic data for the study year in Bingöl, Turkey, as obtained from the meteorology station. According to the long period (1961-2016) data obtained from the Bingöl Meteorological Station located near the experimental site, the annual mean temperature and total precipitation in the region are $12.1^{\circ} \mathrm{C}$ and $943.6 \mathrm{~mm}$, respectively. About $80 \%$ of precipitation falls during November-April period $(761.1 \mathrm{~mm})$. July $(5.6 \mathrm{~mm}$ total precipitation and 26.8 ${ }^{\circ} \mathrm{C}$ mean air temperature) and August $\left(3.2 \mathrm{~mm}\right.$ total precipitation and $26.4{ }^{\circ} \mathrm{C}$ mean air temperature) are the driest and hottest months.

Table 1. The long term average climatic data and climatic data for the study year in Bingöl, Turkey

\begin{tabular}{llcccccc}
\hline Year & \multicolumn{1}{c}{ Month } & $\begin{array}{c}\text { Temperature } \\
\left({ }^{\circ} \mathrm{C}\right)\end{array}$ & $\begin{array}{c}\text { Relative } \\
\text { Humudity } \\
(\%)\end{array}$ & $\begin{array}{c}\text { Wind } \\
\text { speed } \\
\left(\mathrm{m} / \mathrm{s}^{-1}\right)\end{array}$ & $\begin{array}{c}\text { Daily } \\
\text { Sunshine } \\
(\mathrm{h})\end{array}$ & $\begin{array}{c}\text { Evaporation } \\
(\mathrm{mm})\end{array}$ & $\begin{array}{c}\text { Precipition } \\
(\mathrm{mm})\end{array}$ \\
\hline \multirow{2}{*}{ Long } & May & 16.3 & 55.8 & 1.9 & 7.31 & 116.5 & 75.1 \\
term & June & 22.1 & 43.5 & 2.1 & 9.40 & 179.1 & 20.6 \\
$(1960-$ & August & 26.7 & 35.9 & 2.2 & 9.54 & 231.2 & 5.7 \\
$2013)$ & September & 26.4 & 35.1 & 2.1 & 9.24 & 221.7 & 3.3 \\
\hline \multirow{2}{*}{2013} & May & 21.1 & 41.0 & 1.9 & 8.31 & 158.2 & 10.4 \\
\hline & June & 18.7 & 47.8 & 0.87 & 7.20 & 12 & 7.0 \\
& July & 22.8 & 33.3 & 1.04 & 8.84 & 181 & 6.2 \\
& August & 27.2 & 26.4 & 1.28 & 9.39 & 278 & - \\
\hline \multirow{2}{*}{2014} & September & 26.4 & 26.2 & 1.08 & 9.19 & 255 & - \\
& May & 20.3 & 34.5 & 0.83 & 7.95 & 111 & 10.9 \\
\hline & June & 16.7 & 48.9 & 0.96 & 6.56 & 0.95 & 0.41 \\
& July & 22.0 & 34.6 & 1.01 & 8.58 & 215 & 23.4 \\
& August & 27.2 & 25.9 & 0.95 & 8.54 & 216.9 & 4.88 \\
\end{tabular}

${ }^{\&}$ Includes the vegetation period in May and September of 2013-2014

*The precipitation and evaporation values for 2013 were measured using a rain gauge and an A-class evaporation pan installed in the study area.

A profile was dug to determine the soil properties in the study area and disturbed and undisturbed soil samples were collected from the depths of 0-30, 30-60 and 60- $90 \mathrm{~cm}$ of the soil profile, followed by the analyses of the physico, chemical and hydraulic properties of the soil samples (Tables 2).

The Joker- $F_{1}$ (Lycopersicon esculentum) variety was used in the study. In the trials, Joker F1 tomato variety was chosen due to the fact that it is a very strong variety that can cover the fruit, it is more resistant to diseases, it has can highly adapt to the region, it yields a hard fruit with a long shelf-life and it is suitable for temporary and long-term harvest. The seedlings were planted in the field on May 20 2013 and on May 31 2014. Prior to planting, plough cultivation was applied, large clods were crushed and the field surface was smoothed to prepare the conditions for planting. The plants were planted in 5 rows with an inter-row spacing of $100 \mathrm{~cm}$ and intra-row spacing of $50 \mathrm{~cm}$. Weeding was carried out manually through hoeing three times until the first harvest. Nitrogenous, phosphorous and potash fertilizers were used in fertilization. Prior to planting, compound Diammonium Phosphate (DAP) (20:20:0) was applied in the dose of $50 \mathrm{~kg}$ per decare. Equal fertilization to each plant was carried out until reaching a cover level of 30\% and irrigation conditions were met; after planting, in each irrigation, the 15:15:15 and 13-0-46 fertilizers were applied in the amount of $10 \mathrm{~kg}$ (50 kg in total) using a drip 
irrigation system. To control the more cricket population, the Korban-4 insecticide was used after planting. The experiments were carried out using waters of two different qualities in the applications, i.e. freshwater $(\mathrm{FW})$ and treated wastewater (TWW). The plants were drip-irrigated with two different water types, namely recycled wastewater (RW) collected from the Bingöl city wastewater treatment plant and freshwater (FW) obtained from an irrigation network in the region.

Table 2. The physico, chemical and hydraulic properties of experimental field soil prior to the study

\begin{tabular}{llll}
\hline \multirow{2}{*}{ Parameter } & \multicolumn{3}{c}{ Soil layer $(\mathrm{cm})$} \\
\cline { 2 - 4 } & $0-30$ & $30-60$ & $60-90$ \\
\hline Texture & Clay & Clay & Clay \\
Sand, \% & 30.2 & 26.4 & 27.4 \\
Silt, \% & 28.6 & 29.1 & 27.9 \\
Clay, \% & 41.2 & 44.5 & 44.7 \\
Particle density & 2.59 & 2.60 & 2.61 \\
Bulk density, Mg m ${ }^{-3}$ & 1.30 & 1.31 & 1.36 \\
Porosity, \% & 49.8 & 49.6 & 47.9 \\
Wet aggregate stability, \% & 39.8 & 52.9 & 49.2 \\
Field capacity, \% of weight & 28.5 & 30.3 & 30.8 \\
Wilting point, \% of weight & 17.2 & 18.1 & 18.4 \\
AWC, mm & 44.1 & 47.9 & 50.6 \\
pH & 8.01 & 7.94 & 7.92 \\
EC, dS m ${ }^{-1}$ & 0.53 & 0.51 & 0.45 \\
Organic matter, \% & 1.60 & 1.30 & 1.10 \\
CaCO & $\%$
\end{tabular}

AWC: Available water content; EC: Electrical conductivity

Drip irrigation method was used in irrigation. The irrigation strategies comprised full irrigation (100\%), deficit irrigation, which involves the use of $75 \%$ and $50 \%$ of the water used in full irrigation and partial root drying (PRD). In all applications, waters of two different qualities (clean water and wastewater) were used. In each parcel, 6 lateral pipes were installed in the middle of each plant row pair with a spacing of $100 \mathrm{~cm}$; the irrigation water was applied from all lateral pipes in full and deficit irrigation applications, while the irrigation water was alternately applied in the partial root drying method [from no. 1-3-5 lateral pipes in odd-number irrigations; from no. 2-4-6 lateral pipes in even-number irrigations]. The amounts of irrigation waters were equal in wastewater and clean water applications and adjusted in accordance with the control application in which $100 \%$ full irrigation was applied. The irrigations were commenced immediately after planting and finalized on September 29, when the growing season ended.

The proportions of sand, silt, and clay fractions were detected using the Bouyoucos hydrometer method described by Gee and Bauder (1986). The cylinder method was used to determine the soil bulk density, and a pycnometer was used to determine the particle density (Blake and Hartge1986a,b). Soil porosity was calculated from the bulk density and particle density values (Danielson and Sutherland 1986). The wet-sieving method was used to measure the aggregate stability (Kemper and Rosenau 1986). The amount of water retention at field capacity $(-33 \mathrm{kPa})$ and wilting point $(-1.5 \mathrm{MPa})$ were determined with a pressure plate (Cassel and Nielsen 1986). Available water content was calculated as the difference between water retained at field capacity and at the wilting point.

Infiltration measurements were conducted one month after the last harvest on each plot in both experimental years by double-ring infiltrometers under constant freshwater head for 420 minutes. The measurements had also been carried out in the study field prior to the experiment. Infiltration measurement data was analyzed using regression to obtain a Kostiakov model parameter values for each treatment. 
The variance analyses were carried out using the SAS software (Anonymous, 2000) and the Duncan multiple comparison test of the Minitab software was used to compare the significant averages (Kesici and Kocabaş, 2007).

\section{Results and discussion}

\section{The quality of irrigation waters and irrigation quantities}

The $\mathrm{pH}, \mathrm{EC}$, and TSS values in the waters given in Table 3 were suitable for irrigation considering the standards proposed by the FAO (6.5-8.4 for $\mathrm{pH},<0.7 \mathrm{dS} \mathrm{m}^{-1}$ for EC, and $<50 \mathrm{mg} \mathrm{l}^{-1}$ for TSS) and their quality were in good class (Ayers and Westcot 1985). Although $\mathrm{SO}_{4}^{2-}\left(<200 \mathrm{mg} \mathrm{l}^{-1}\right), \mathrm{Na}^{+}\left(<125 \mathrm{mg} \mathrm{l}^{-1}\right)$ and $\mathrm{B}\left(<1 \mathrm{mg}^{-1}\right)$ concentrations in the waters were low according to Turkish national water pollution control regulation (WPCR) standards, recycled wastewater (RW) was the water with increasing problem due to a $\mathrm{Cl}^{-}$concentration of higher than $>25 \mathrm{mg} \mathrm{l}^{-1}$ (WPCR, 2008). Total $\mathrm{N}\left(>5 \mathrm{mg} \mathrm{l}^{-1}\right)$ and $\mathrm{P}(>0.65$ $\left.\mathrm{mg} \mathrm{l}^{-1}\right)$ values in $\mathrm{RW}$ were too high. While the $\mathrm{Fe}\left(<0.30 \mathrm{mg} \mathrm{l}^{-1}\right)$, Mn $\left(<0.10 \mathrm{mg} \mathrm{l}^{-1}\right)$ and $\mathrm{Zn}(<0.20 \mathrm{mg}$ $\mathrm{I}^{-1}$ ) concentrations in RW and freshwater (FW) provided the best quality for irrigation, in RW treatment $\mathrm{Cu}\left(0.05-0.20 \mathrm{mg} \mathrm{l}^{-1} ; 2^{\text {nd }}-3^{\text {rd }}\right.$ class water $), \mathrm{Cd}\left(>0.01 \mathrm{mg} \mathrm{l}^{-1} ; 4^{\text {th }}\right.$ class water $), \mathrm{Ni}\left(0.02-0.05 \mathrm{mg} \mathrm{l}^{-1} ; 1^{\text {st }}-2^{\text {nd }}\right.$ class water), $\mathrm{Pb}\left(>0.05 \mathrm{mg} \mathrm{l}^{-1} ; 4^{\text {th }}\right.$ class water $), \mathrm{Co}\left(0.02-0.20 \mathrm{mg} \mathrm{l}^{-1} ; 2^{\text {nd }}-3^{\text {rd }}\right.$ class water $)$, and $\mathrm{Cr}(>0.20$ $\mathrm{mg} \mathrm{l^{-1 }} ; 4^{\text {th }}$ class water) concentrations exhibited lower quality (WPCR 2008). Current $\mathrm{Cu}, \mathrm{Cd}, \mathrm{Ni}, \mathrm{Co}$, and $\mathrm{Cr}$ concentrations in FW also lowered irrigation water quality of this type of water. SAR value was low in both water types according to the USSL classification (Kanber and Ünlü, 2010).

Table 3. Physical and chemical properties values (mean \pm SEM) of the waters used in irrigation

\begin{tabular}{|c|c|c|c|c|c|}
\hline \multirow{2}{*}{ Property } & \multirow{2}{*}{ Unit } & \multicolumn{2}{|l|}{2013} & \multicolumn{2}{|l|}{2014} \\
\hline & & RW & $\overline{F W}$ & RW & FW \\
\hline $\mathrm{pH}$ & - & $7.76 \pm 0.34$ & $8.15 \pm 0.22$ & $7.73 \pm 0.24$ & $7.57 \pm 0.08$ \\
\hline $\mathrm{EC}$ & $\mathrm{dS} \mathrm{m}^{-1}$ & $0.51 \pm 0.02$ & $0.16 \pm 0.01$ & $0.42 \pm 0.03$ & $0.24 \pm 0.03$ \\
\hline TSS & $\mathrm{mg} \mathrm{l}^{-1}$ & $21.4 \pm 3.5$ & $20.1 \pm 1.2$ & $16.7 \pm 3.3$ & $12.1 \pm 2.3$ \\
\hline Total N & $\mathrm{mg} \mathrm{l}^{-1}$ & $13.8 \pm 0.6$ & - & $12.6 \pm 0.5$ & - \\
\hline Total P & $\mathrm{mg} \mathrm{l}^{-1}$ & $1.94 \pm 0.04$ & - & $1.65 \pm 0.09$ & - \\
\hline $\mathrm{Ca}$ & me $1^{-1}$ & $2.09 \pm 0.29$ & $1.10 \pm 0.10$ & $1.75 \pm 0.37$ & $1.50 \pm 0.40$ \\
\hline $\mathrm{Mg}$ & me $1^{-1}$ & $1.32 \pm 0.28$ & $0.78 \pm 0.03$ & $0.89 \pm 0.17$ & $0.65 \pm 0.06$ \\
\hline $\mathrm{Na}$ & $\mathrm{me}^{-1}$ & $1.17 \pm 0.44$ & $0.17 \pm 0.03$ & $1.47 \pm 0.12$ & $0.19 \pm 0.01$ \\
\hline $\mathrm{K}$ & me $1^{-1}$ & $0.35 \pm 0.11$ & $0.05 \pm 0.01$ & $0.33 \pm 0.02$ & $0.11 \pm 0.02$ \\
\hline $\mathrm{CO}_{3}$ & me $1^{-1}$ & $0.03 \pm 0.03$ & $0.01 \pm 0.01$ & - & - \\
\hline $\mathrm{HCO}_{3}$ & me $1^{-1}$ & $0.37 \pm 0.07$ & $0.28 \pm 0.03$ & $0.35 \pm 0.08$ & $0.26 \pm 0.06$ \\
\hline $\mathrm{SO}_{4}$ & me $1^{-1}$ & $3.21 \pm 0.34$ & $1.35 \pm 0.07$ & $2.51 \pm 0.43$ & $1.64 \pm 0.03$ \\
\hline $\mathrm{Cl}$ & $\mathrm{me}^{-1}$ & $1.24 \pm 0.41$ & $0.44 \pm 0.12$ & $1.50 \pm 0.40$ & $0.50 \pm 0.26$ \\
\hline B & $\mathrm{mg} \mathrm{l}^{-1}$ & $0.43 \pm 0.12$ & $0.25 \pm 0.11$ & $0.41 \pm 0.13$ & $0.19 \pm 0.10$ \\
\hline $\mathrm{Fe}$ & $\mathrm{mg} \mathrm{l}^{-1}$ & $0.23 \pm 0.11$ & $0.13 \pm 0.05$ & $0.12 \pm 0.01$ & $0.15 \pm 0.01$ \\
\hline $\mathrm{Zn}$ & $\mathrm{mg} \mathrm{l}^{-1}$ & $0.06 \pm 0.01$ & $0.04 \pm 0.00$ & $0.02 \pm 0.00$ & $0.01 \pm 0.00$ \\
\hline $\mathrm{Cu}$ & $\mathrm{mg} \mathrm{l}^{-1}$ & $0.09 \pm 0.02$ & $0.05 \pm 0.02$ & - & - \\
\hline $\mathrm{Mn}$ & $\mathrm{mg} \mathrm{l}^{-1}$ & $0.07 \pm 0.03$ & $0.03 \pm 0.01$ & $0.04 \pm 0.003$ & $0.01 \pm 0.00$ \\
\hline $\mathrm{Cd}$ & $\mathrm{mg} \mathrm{l}^{-1}$ & $0.06 \pm 0.03$ & $0.04 \pm 0.02$ & $0.08 \pm 0.01$ & $0.07 \pm 0.01$ \\
\hline $\mathrm{Ni}$ & $\mathrm{mg} \mathrm{l}^{-1}$ & $0.04 \pm 0.01$ & $0.04 \pm 0.003$ & $0.05 \pm 0.01$ & $0.02 \pm 0.01$ \\
\hline $\mathrm{Pb}$ & $\mathrm{mg} \mathrm{l}^{-1}$ & $0.06 \pm 0.02$ & $0.05 \pm 0.01$ & $0.04 \pm 0.00$ & $0.03 \pm 0.00$ \\
\hline Co & $\mathrm{mg} \mathrm{l}^{-1}$ & $0.19 \pm 0.00$ & $0.17 \pm 0.003$ & $0.19 \pm 0.01$ & $0.15 \pm 0.02$ \\
\hline $\mathrm{Cr}$ & $\mathrm{mg} \mathrm{l}^{-1}$ & $0.41 \pm 0.03$ & $0.34 \pm 0.05$ & $0.34 \pm 0.04$ & $0.29 \pm 0.04$ \\
\hline SAR & - & $0.95 \pm 0.42$ & $0.18 \pm 0.04$ & $1.32 \pm 0.19$ & $0.19 \pm 0.01$ \\
\hline
\end{tabular}

SEM: Standard error of the mean; RW: Recycled wastewater; FW: Freshwater; EC: Electrical conductivity;

TSS: Total suspended solids; SAR: Sodium adsorption ratio

Table 4 shows the amounts of monthly irrigation water applied in the irrigation practices. Equal amounts of irrigation water were applied in the RW and FW treatments in each irrigation practice. A total of 23 irrigations were applied in both years. Seasonal irrigation quantities in full irrigation (FI) practice were 
$640.2 \mathrm{~mm}$ in 2013 and $648.1 \mathrm{~mm}$ in 2014. Considering the two-year average data, while Deficit Irrigation-I (DI25) and Partial Root-zone Drying Irrigation-I (PRD25) practices were irrigated with 23.3\% less irrigation water when compared with the FI practice, Deficit Irrigation-II (DI50) and Partial Root-zone Drying Irrigation-II (PRD50) practices received 46.5\% less water. Deep percolation below root zone from precipitation and irrigation quantities during the growing periods in both years did not occur. Reduced irrigation quantities provided less soil moisture contents in the DI and the PRD practices compared with the FI practice. However, soil moisture content did not reduce below the wilting point in either practice. Soil moisture content had the most decreased amount in the PRD50 practice between all of the practices.

Table 4. Monthly irrigation quantities applied to irrigation practices in experiment years (mm)

\begin{tabular}{llllllll}
\hline Year & Practice & \multicolumn{7}{c}{ Month } \\
\cline { 3 - 7 } & & May & June & July & August & September & Total \\
\hline 2013 & FI & 10.6 & 37 & 219 & 207.6 & 166.1 & 640.2 \\
& DI25 & 10.6 & 34.2 & 164.3 & 155.7 & 124.6 & 489.3 \\
& DI50 & 10.6 & 31.4 & 109.5 & 103.8 & 83.1 & 338.3 \\
& PRD25 & 10.6 & 34.2 & 164.3 & 155.7 & 124.6 & 489.3 \\
& PRD50 & 10.6 & 31.4 & 109.5 & 103.8 & 83.1 & 338.3 \\
\hline 2014 & FI & 4 & 33.2 & 141.6 & 256 & 213.3 & 648.1 \\
& DI25 & 4 & 33.2 & 110.3 & 192 & 160 & 499.5 \\
& DI50 & 4 & 33.2 & 79.1 & 128 & 106.7 & 350.9 \\
& PRD25 & 4 & 33.2 & 110.3 & 192 & 160 & 499.5 \\
& PRD50 & 4 & 33.2 & 79.1 & 128 & 106.7 & 350.9 \\
\hline
\end{tabular}

FI: Full irrigation, DI25 and DI50: 25 and 50\% deficit irrigation, PRD25 and PRD50: 25 and 50\% deficit irrigation with PRD technique

\section{Soil physical properties}

Bulk density, particle density, porosity, and wet aggregate stability values were determined as the soil physical properties in three soil layers under different irrigation water types and irrigation practice conditions and they were found statistically similar in 2013 and 2014. The figures 1-4 show combined results of experiment years for bulk density, particle density, porosity, and wet aggregate stability, respectively. As shown in these figures, soil physical properties did not change statistically with the irrigation water types and the irrigation practices in soil layers of 30-60 and 60-90 cm. In the 0-30 cm soil layer, while RW irrigation significantly increased the wet aggregate stability by $3.8 \%$ compared with the FW irrigation, particle density was decreased by $0.4 \%$ (Figs. 2 and 4). Particle density in 0-30 $\mathrm{cm}$ soil layer was also significantly reduced by $1.1 \%$ in the DI50 practice compared with the FI practice (Fig. 2). Although there was a significant difference between DI25 practice with the highest bulk density value and PRD50 practice with the lowest bulk density value, the values obtained in both practices were statistically similar to the value in the FI practice (Fig. 1). The DI25 practice, which had the highest bulk and particle density values in $0-30 \mathrm{~cm}$ soil layer, lowered porosity and also had a lower value than the FI practice (Fig. 3). 


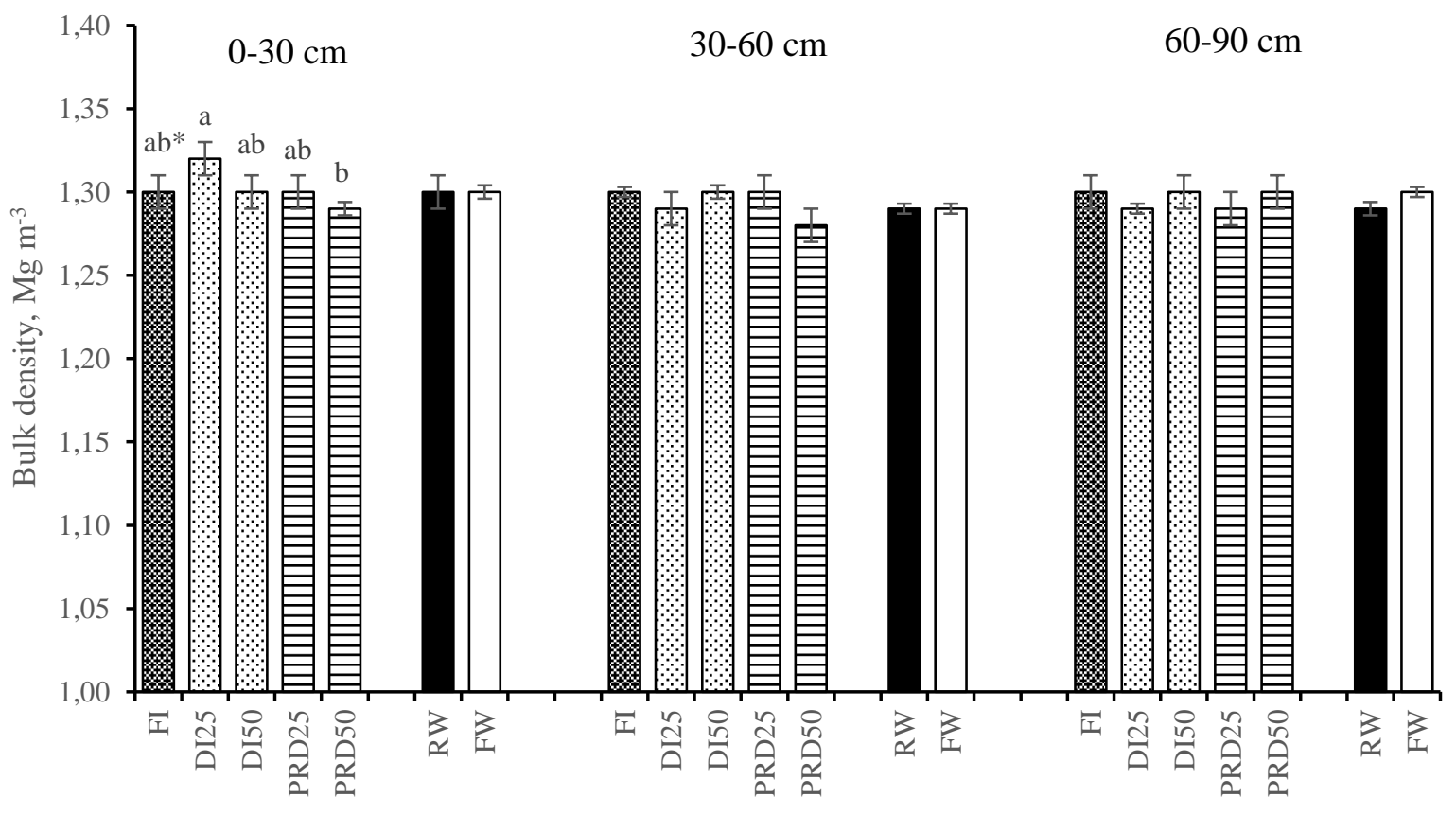

Treatments

Fig. 1 The bulk density values as two-year average in three soil layers in different irrigation practices and water types. The mean values marked with different letters are significantly different $(*$ : P < 0.05$)$. FI: Full irrigation, DI25 and DI50: 25 and 50\% deficit irrigation, PRD25 and PRD50: 25 and 50\% deficit irrigation with PRD technique, RW: Recycled wastewater, FW: Freshwater

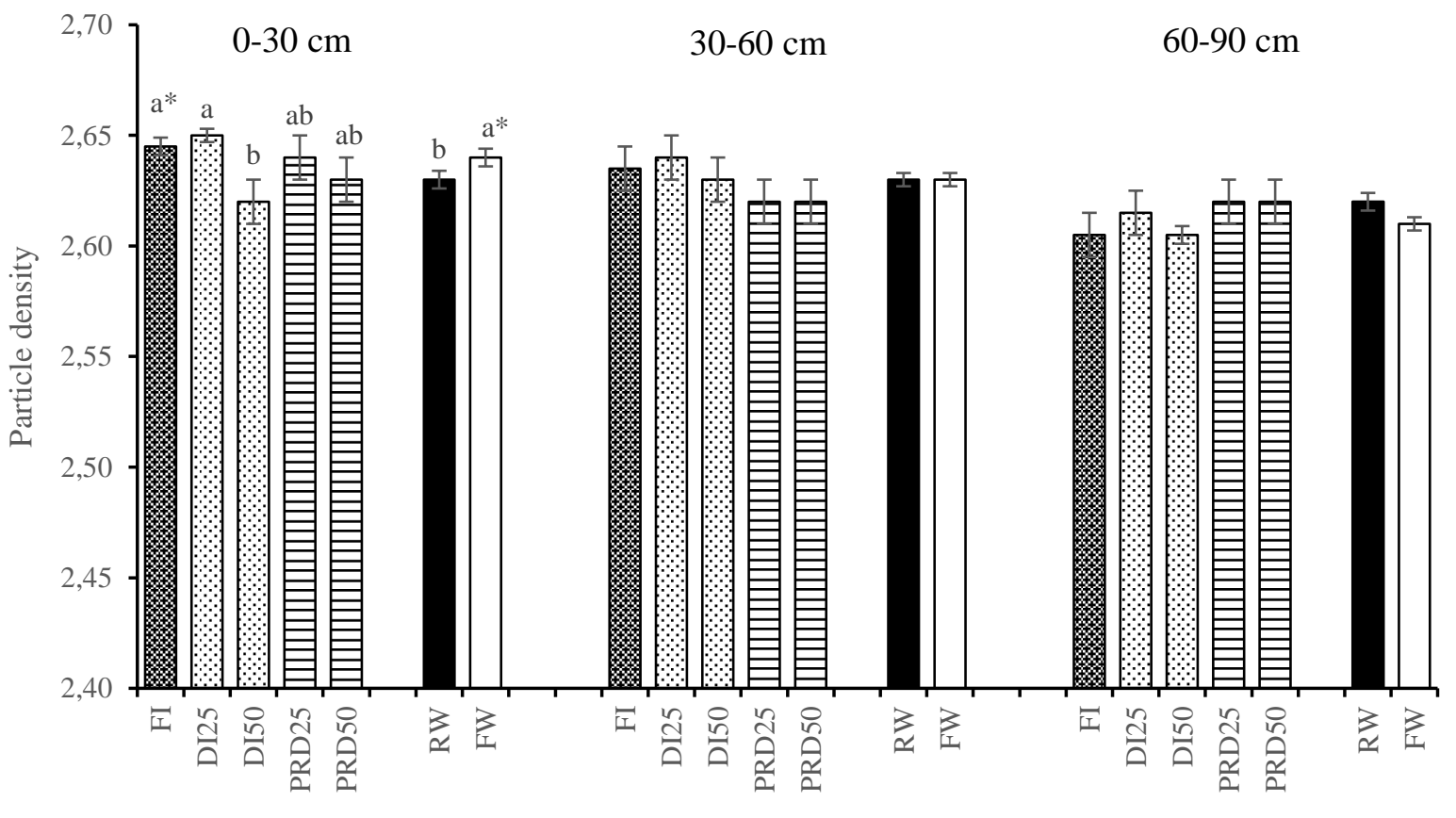

Treatments

Fig. 2 The particle density values as two-year average in three soil layers in different irrigation practices and water types. The mean values marked with different letters are significantly different $(*: \mathrm{P}<0.05)$. Explanations of the abbreviations are as shown in Fig 1 


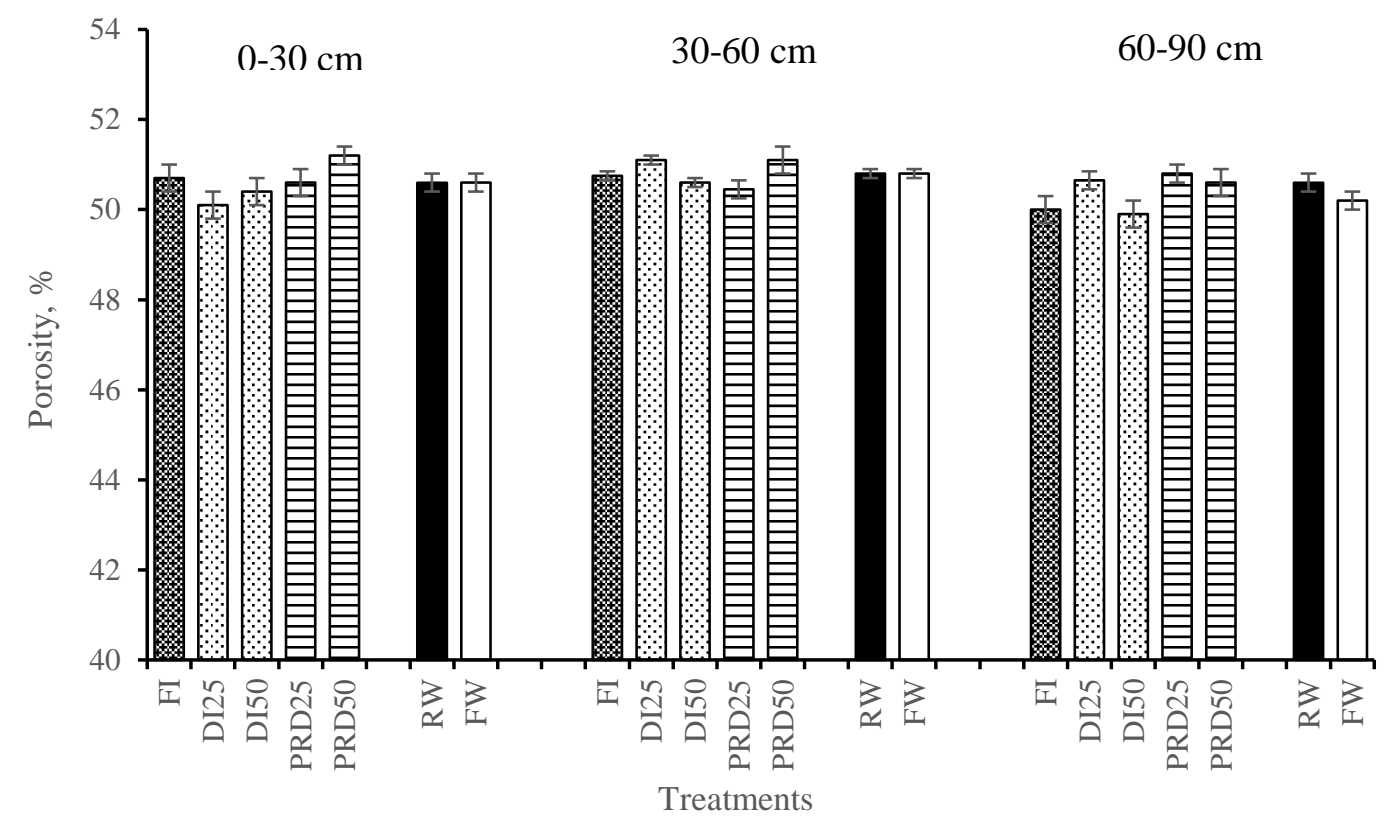

Fig. 3 The porosity values as two-year average in three soil layers in different irrigation practices and water types. Explanations of the abbreviations are as shown in Fig 1

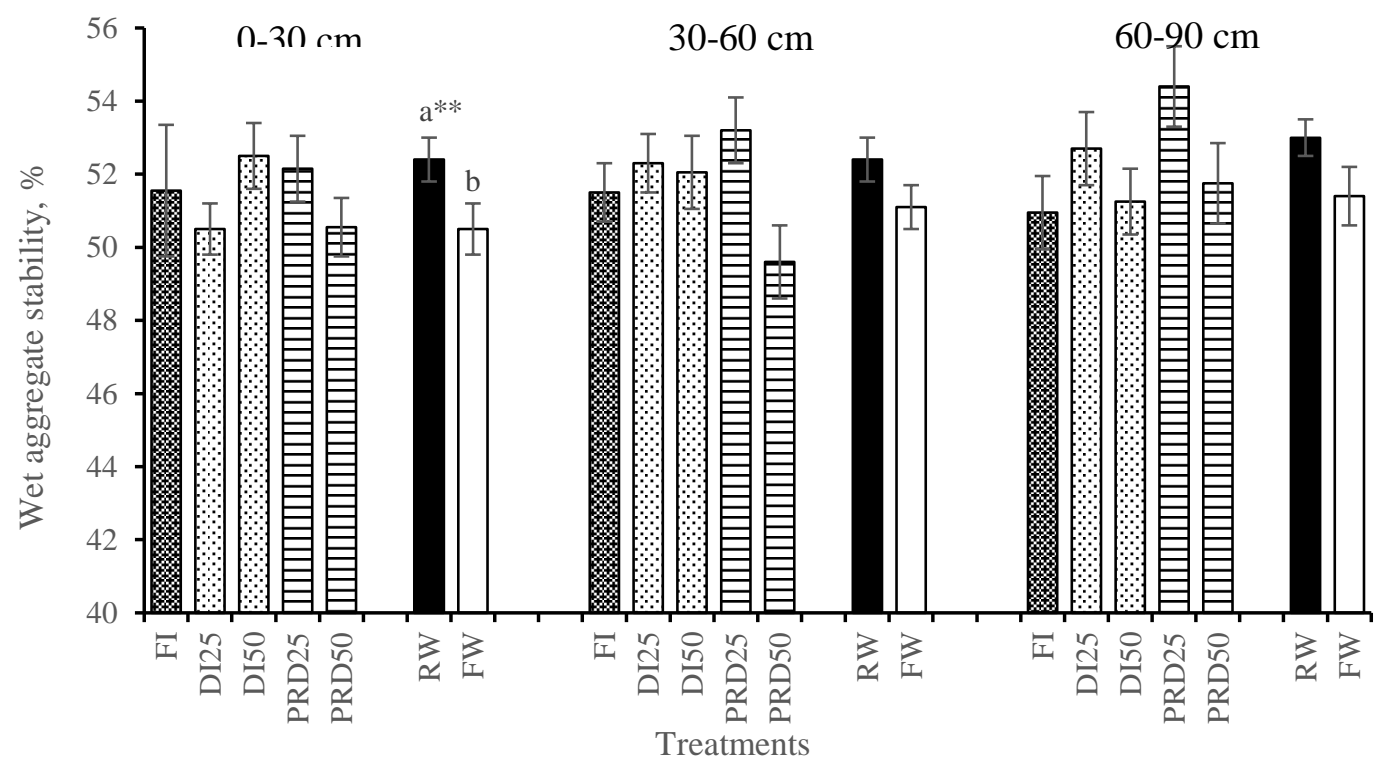

Fig. 4 The wet aggregate stability values as two-year average in three soil layers in different irrigation practices and water types. The mean values marked with different letters are significantly different $(* *$ : $\mathrm{P}<0.01)$. Explanations of the abbreviations are as shown in Fig 1

The bulk density values in 0-30 cm soil layer under the DI25, DI50, and PRD25 practices irrigated with RW were higher than subsoil layers. Although the bulk density values for all practices in 0-30 and 30$60 \mathrm{~cm}$ soil layers irrigated with both water types were near the values of pre-planting in Table 1, the values in $60-90 \mathrm{~cm}$ soil layer after experiments were about 5\% lower. Particle density values in 60-90 $\mathrm{cm}$ soil layer for all practices in both water types were lower than the values in topsoil layers (0-30 and $30-60 \mathrm{~cm}$ ) (Fig 2). The particle density values for all practices at the end of the experiment in three soil layers under RW and FW irrigation conditions were generally higher than the initial values (Table 2). 
Particle densities in 0-30 and 30-60 cm soil layers resulted in about a $2 \%$ increase. In $60-90 \mathrm{~cm}$ soil layer, increase rates were less. The porosity values in three soil layers irrigated with both water types observed after the experiment were higher than the initial values (Table 2). The PRD50 practice generally had the highest values in all soil layers (Fig. 3). The porosity values obtained in the PRD50 practice in 0-30, 30-60 and 60-90 cm soil layers irrigated with RW were by 2.2, 3.2, and 6.9\% higher than the initial values, respectively. Considering the initial wet aggregate stability values in Table 1 , remarkable improvements in 0-30 and $60-90 \mathrm{~cm}$ soil layers were observed in the RW treatment. Wet aggregate stability in the surface soil layer $(0-30 \mathrm{~cm})$ was the highest in the plots fully irrigated with RW. In 30-60 and 60-90 cm soil layers, the PRD25 practice that was irrigated with wastewater provided the highest values as 5.4 and $10.0 \%$, which are also higher values compared with the FI practice, respectively (Fig. 4). However, PRD25 treatment had the lowest value in the 0-30 cm soil layer under the wastewater irrigation conditions. The wet aggregate stability in the PRD25 practice was by $11.5 \%$ lower than the value in FI practice. This finding could be associated with the ESP value in Table 5. Compared with the other practices, ESP value in the PRD25 practice was high in 0-30 cm soil layer and low in 30-60 and 60-90 cm soil layers. The increase of ESP may importantly decrease the aggregate stability (García-Orenes et al., 2005; Schacht and Marschner, 2015).

Our results indicated that the soil salinity-sodicity was too low and non-significant changes for the OM in soil under different water types and practices were observed, and solid material content in the waters was too low as well (12.1-21.4 $\mathrm{mg}^{-1}$ ) (Table 3). Moreover, the wetting-drying cycles due to different irrigation practices and the changes in rooting volume may affect the soil physical properties (Gould et al., 2016; Wang et al., 2015). Significant findings for bulk density, particle density, and porosity in different water types and irrigation practices could not be determined due to many reasons that are mentioned above. The particle density depends on soil mineral composition and the degree of organic matter decomposition (Rühlmann et al., 2006). Although soil OM content observed after harvesting was higher than the initial values, there was no significant difference in soil OM content under the conditions irrigated with both water resources (Table 5). Moreover, the amount of suspended solids in both water types was not considerable (Table 2). Therefore, it could be said that a very low difference in particle density between the RW and FW may be a result of less decomposition of organic matter only. Some researchers showed that irrigation with wastewater had non-significant effects on soil physical properties. Gonçalves et al. (2010) and Tunc and Sahin (2015) observed that the variation of soil bulk density was insignificant in the wastewater and freshwater applied plots. Magesan (2001) expressed that treated wastewater irrigation did not change the bulk density, particle density, and porosity. Many studies have shown that wastewater irrigation improved the porosity and bulk density because of the presence of higher soil OM compared with freshwater irrigation conditions (Beigi and Banitalebi, 2013; Biswas et al., 2017; Mojiri, 2011; Mojid and Wyseure, 2013; Vogeler, 2009). However, some researchers found the opposite results for bulk density and porosity due to dispersion and sedimentation under the wastewater irrigation conditions (Abedi-Koupai et al., 2006; Aiello et al., 2007; Coppola et al., 2004). Higher wet aggregate stability under RW treatment could be explained by lower $\mathrm{CaCO}_{3}$ content in $0-30 \mathrm{~cm}$ soil layer, because dissolved $\mathrm{CaCO}_{3}$ in the soil under the wastewater application conditions may be induced to higher aggregation. Tayel et al. (2010) also determined a significant positive correlation between the soil aggregation and the $\mathrm{CaCO}_{3}$ content in the soil. Furthermore, $\mathrm{Ca}$ and $\mathrm{Mg}$ cations in wastewater, by way of cationic bridging between clay and organic matter, could increase the formation of micro aggregates that cause aggregation (Bronick and Lal, 2005;DuránÁlvarez and Jiménez-Cisneros, 2014). 
Table 5. $\mathrm{pH}$, electrical conductivity (EC), organic matter $(\mathrm{OM}), \mathrm{CaCO}_{3}$, cation exchange capacity (CEC), and exchangeable sodium percentage (ESP) values (mean \pm SEM) in three different layers $(0-30,30-60$, and 60-90 cm) of the soil irrigated with recycled water $(\mathrm{RW})$ and freshwater $(\mathrm{FW})$ under different irrigation practices in 2013-14

\begin{tabular}{|c|c|c|c|c|c|c|c|c|c|c|c|c|c|c|c|c|c|c|}
\hline \multirow{2}{*}{$\begin{array}{l}\text { Soil } \\
\text { layer }\end{array}$} & \multirow[t]{2}{*}{ Parameter } & \multicolumn{2}{|l|}{ FI } & \multicolumn{2}{|l|}{ DI25 } & \multicolumn{2}{|l|}{ DI50 } & \multicolumn{2}{|l|}{ PRD25 } & \multicolumn{2}{|l|}{ PRD50 } & \multicolumn{7}{|c|}{ General mean } \\
\hline & & RW & FW & RW & FW & $\mathrm{RW}$ & FW & RW & FW & RW & FW & RW & FW & FI & DI25 & DI50 & PRD25 & PRD50 \\
\hline \multirow[t]{6}{*}{$0-30$} & $\mathrm{pH}$ & $7.85 \pm 0.07$ & $7.83 \pm 0.07$ & $7.82 \pm 0.06$ & $7.77 \pm 0.07$ & $7.85 \pm 0.06$ & $7.94 \pm 0.04$ & $7.86 \pm 0.05$ & $7.91 \pm 0.03$ & $7.87 \pm 0.05$ & $7.89 \pm 0.07$ & 7.85 & 7.87 & 7.84 & 7.80 & 7.89 & 7.88 & 7.88 \\
\hline & $\mathrm{EC}, \mathrm{dS} \mathrm{m}^{-1}$ & $0.77 \pm 0.04$ & $0.70 \pm 0.03$ & $0.63 \pm 0.04$ & $0.64 \pm 0.03$ & $0.56 \pm 0.02$ & $0.58 \pm 0.03$ & $0.65 \pm 0.04$ & $0.64 \pm 0.05$ & $0.62 \pm 0.01$ & $0.56 \pm 0.03$ & 0.65 & 0.62 & $0.74 \mathrm{a}^{* *}$ & $0.63 b c$ & $0.57 \mathrm{c}$ & $0.65 b$ & $0.59 \mathrm{bc}$ \\
\hline & $\mathrm{OM}, \%$ & $2.41 \pm 0.13$ & $2.32 \pm 0.13$ & $2.28 \pm 0.16$ & $2.24 \pm 0.14$ & $2.20 \pm 0.16$ & $2.15 \pm 0.21$ & $2.33 \pm 0.14$ & $2.24 \pm 0.16$ & $2.19 \pm 0.17$ & $2.12 \pm 0.10$ & 2.28 & 2.21 & 2.36 & 2.26 & 2.18 & 2.29 & 2.16 \\
\hline & $\mathrm{CaCO}_{3}, \%$ & $3.73 \pm 0.27$ & $4.27 \pm 0.18$ & $3.89 \pm 0.29$ & $4.31 \pm 0.20$ & $4.19 \pm 0.18$ & $3.81 \pm 0.26$ & $3.74 \pm 0.18$ & $4.24 \pm 0.20$ & $3.54 \pm 0.26$ & $3.92 \pm 0.16$ & $3.82 b^{*}$ & $4.11 \mathrm{a}$ & 4.00 & 4.10 & 4.00 & 3.99 & 3.73 \\
\hline & $\mathrm{CEC}, \mathrm{cmol} \mathrm{kg}{ }^{-1}$ & $32.5 \pm 1.2$ & $34.5 \pm 0.9$ & $31.4 \pm 1.4$ & $33.6 \pm 0.3$ & $31.2 \pm 1.6$ & $33.4 \pm 1.0$ & $35.5 \pm 1.3$ & $33.5 \pm 1.0$ & $31.5 \pm 1.5$ & $32.1 \pm 0.4$ & 32.4 & 33.4 & 33.5 & 32.5 & 32.3 & 34.5 & 31.8 \\
\hline & ESP, $\%$ & $2.20 \pm 0.10$ & $1.68 \pm 0.09$ & $2.03 \pm 0.15$ & $1.60 \pm 0.08$ & $1.81 \pm 0.11$ & $1.73 \pm 0.23$ & $1.94 \pm 0.17$ & $1.86 \pm 0.20$ & $1.76 \pm 0.17$ & $1.77 \pm 0.14$ & $1.95 \mathrm{a}^{*}$ & $1.73 \mathrm{~b}$ & 1.94 & 1.82 & 1.77 & 1.90 & 1.77 \\
\hline \multirow[t]{6}{*}{$30-60$} & $\mathrm{pH}$ & $7.85 \pm 0.04$ & $7.90 \pm 0.03$ & $7.78 \pm 0.04$ & $7.82 \pm 0.04$ & $7.81 \pm 0.03$ & $7.91 \pm 0.04$ & $7.92 \pm 0.04$ & $7.88 \pm 0.03$ & $7.90 \pm 0.03$ & $7.94 \pm 0.03$ & 7.85 & 7.89 & 7.87ab* & $7.80 \mathrm{~b}$ & $7.86 \mathrm{ab}$ & $7.90 \mathrm{a}$ & $7.92 \mathrm{a}$ \\
\hline & $\mathrm{EC}, \mathrm{dS} \mathrm{m}^{-1}$ & $0.77 \pm 0.05$ & $0.63 \pm 0.04$ & $0.67 \pm 0.05$ & $0.59 \pm 0.05$ & $0.70 \pm 0.04$ & $0.49 \pm 0.02$ & $0.70 \pm 0.05$ & $0.60 \pm 0.02$ & $0.64 \pm 0.05$ & $0.56 \pm 0.02$ & $0.70 a^{* *}$ & $0.57 \mathrm{~b}$ & 0.70 & 0.63 & 0.59 & 0.65 & 0.60 \\
\hline & $\mathrm{OM}, \%$ & $2.38 \pm 0.20$ & $2.29 \pm 0.15$ & $2.23 \pm 0.15$ & $2.17 \pm 0.14$ & $2.12 \pm 0.06$ & $2.09 \pm 0.26$ & $2.21 \pm 0.15$ & $2.06 \pm 0.12$ & $2.16 \pm 0.13$ & $2.09 \pm 0.10$ & 2.22 & 2.14 & 2.34 & 2.20 & 2.10 & 2.14 & 2.12 \\
\hline & $\mathrm{CaCO}_{3}, \%$ & $4.11 \pm 0.43$ & $4.12 \pm 0.32$ & $3.66 \pm 0.21$ & $4.14 \pm 0.17$ & $3.99 \pm 0.18$ & $3.98 \pm 0.16$ & $3.77 \pm 0.16$ & $3.98 \pm 0.21$ & $3.68 \pm 0.23$ & $3.82 \pm 0.15$ & 3.84 & 4.01 & 4.12 & 3.90 & 3.99 & 3.87 & 3.75 \\
\hline & $\mathrm{CEC}, \mathrm{cmol} \mathrm{kg}{ }^{-1}$ & $35.4 \pm 0.9$ & $32.6 \pm 1.0$ & $32.2 \pm 0.6$ & $33.4 \pm 0.7$ & $33.4 \pm 1.0$ & $32.8 \pm 1.0$ & $35.5 \pm 1.1$ & $34.4 \pm 1.2$ & $34.5 \pm 1.2$ & $33.4 \pm 1.0$ & 34.2 & 33.3 & 34.0 & 32.8 & 33.1 & 34.9 & 34.0 \\
\hline & ESP, \% & $2.09 \pm 0.14$ & $2.01 \pm 0.18$ & $1.99 \pm 0.13$ & $1.77 \pm 0.11$ & $2.06 \pm 0.12$ & $1.65 \pm 0.12$ & $1.85 \pm 0.09$ & $1.67 \pm 0.09$ & $1.96 \pm 0.14$ & $1.87 \pm 0.10$ & $1.99 \mathrm{a}^{*}$ & $1.79 \mathrm{~b}$ & 2.05 & 1.88 & 1.86 & 1.76 & 1.92 \\
\hline \multirow[t]{6}{*}{$60-90$} & $\mathrm{pH}$ & $7.87 \pm 0.05$ & $7.85 \pm 0.06$ & $7.92 \pm 0.04$ & $7.92 \pm 0.03$ & $7.89 \pm 0.06$ & $7.91 \pm 0.02$ & $7.86 \pm 0.04$ & $7.91 \pm 0.03$ & $7.91 \pm 0.03$ & $7.84 \pm 0.05$ & 7.89 & 7.88 & 7.86 & 7.92 & 7.90 & 7.88 & 7.87 \\
\hline & $\mathrm{EC}, \mathrm{dS} \mathrm{m}^{-1}$ & $0.64 \pm 0.06$ & $0.62 \pm 0.03$ & $0.60 \pm 0.02$ & $0.58 \pm 0.03$ & $0.52 \pm 0.02$ & $0.57 \pm 0.03$ & $0.63 \pm 0.03$ & $0.58 \pm 0.04$ & $0.56 \pm 0.05$ & $0.53 \pm 0.03$ & 0.59 & 0.58 & 0.63 & 0.59 & 0.54 & 0.61 & 0.54 \\
\hline & $\mathrm{OM}, \%$ & $2.39 \pm 0.20$ & $2.21 \pm 0.12$ & $2.01 \pm 0.14$ & $2.0 \pm 0.07$ & $1.95 \pm 0.12$ & $1.88 \pm 0.09$ & $1.90 \pm 0.17$ & $1.87 \pm 0.16$ & $1.80 \pm 0.15$ & $1.95 \pm 0.09$ & 2.01 & 1.98 & $2.30 \mathrm{a}^{* *}$ & $2.00 \mathrm{~b}$ & $1.92 \mathrm{~b}$ & $1.89 \mathrm{~b}$ & $1.87 \mathrm{~b}$ \\
\hline & $\mathrm{CaCO}_{3}, \%$ & $3.89 \pm 0.42$ & $4.60 \pm 0.22$ & $4.30 \pm 0.33$ & $4.21 \pm 0.35$ & $3.71 \pm 0.13$ & $4.21 \pm 0.23$ & $4.45 \pm 0.24$ & $4.52 \pm 0.18$ & $3.66 \pm 0.15$ & $3.93 \pm 0.22$ & 4.00 & 4.30 & 4.24 & 4.26 & 3.96 & 4.48 & 3.80 \\
\hline & $\mathrm{CEC}, \mathrm{cmol} \mathrm{kg}^{-1}$ & $34.5 \pm 1.2$ & $33.6 \pm 1.14$ & $35.1 \pm 1.0$ & $33.6 \pm 0.9$ & $33.5 \pm 1.0$ & $32.2 \pm 0.4$ & $35.8 \pm 0.9$ & $34.4 \pm 0.5$ & $37.3 \pm 1.1$ & $32.7 \pm 0.6$ & $35.2 \mathrm{a}^{* *}$ & $33.3 \mathrm{~b}$ & $34.0 \mathrm{ab}^{*}$ & $34.3 \mathrm{ab}$ & $32.9 \mathrm{~b}$ & $35.1 \mathrm{a}$ & $35.0 \mathrm{a}$ \\
\hline & ESP, $\%$ & $2.08 \pm 0.12$ & $1.90 \pm 0.05$ & $1.92 \pm 0.14$ & $1.88 \pm 0.10$ & $1.99 \pm 0.20$ & $1.88 \pm 0.14$ & $1.70 \pm 0.16$ & $1.71 \pm 0.15$ & $1.59 \pm 0.08$ & $1.93 \pm 0.07$ & 1.85 & 1.86 & 1.99 & 1.90 & 1.93 & 1.70 & 1.76 \\
\hline
\end{tabular}

The values marked with the same letters for different water qualities or irrigation practices in each line of the "general mean" column of each soil layer are not significantly different $(* *: P<0.01$ or *: P<0.05). SEM: Standard error of the mean; FI: Full irrigation, DI25 and DI50: 25 and 50\% deficit irrigation, PRD25 and PRD50: 25 and 50\% deficit irrigation with PRD technique 


\section{Soil hydraulic properties}

\section{Field capacity, wilting point, and available water content}

The results obtained for field capacity (water retained at $-33 \mathrm{kPa}$ ), wilting point (water retained at -1.5 $\mathrm{MPa}$ ) and available water content were found statistically similar in both trial years. Considering the average values of two-years, generally, there were no significant changes in these parameters under different water types and practices in surface and subsoil layers. Field capacity values in two-year average data for 0-30 and 30-60 cm soil layers in the FW treatment were higher than RW treatment values (Fig. 5). Only the change in $60-90 \mathrm{~cm}$ soil layer was important, and the field capacity value in $60-90 \mathrm{~cm}$ soil layer was found $31.1 \%$ for FW and $31.5 \%$ for RW. The lowest field capacity values were determined in surface soil layer compared with sub soil layers. Field capacity values in three soil layers under different water types and practices were higher than the initial values in Table 2. Compared with the initial values, the increase rates in the RW and FW treatments were 8.4 and $8.8 \%$ in $0-30 \mathrm{~cm}$ soil layer, 2.6 and $3.0 \%$ in $30-60 \mathrm{~cm}$ soil layer, and 2.3 and $1.0 \%$ in $60-90 \mathrm{~cm}$ soil layer, respectively. The field capacity values were observed higher by $9.1,4.3$, and 3.6\% in 0-30, 30-60 and 60-90 cm soil layers, respectively in the fully irrigated RW treatment compared to pre-planting values. Similarly, Darvishi (2014) determined that the field capacity was higher in both domestic and agronomical water irrigation conditions compared with the pre-irrigation value, and was $11 \%$ higher than the field capacity under the irrigation with domestic wastewater. Tunc and Sahin (2015) found higher field capacity values in two soil layers of 0-20 and 20-40 cm of the soils irrigated with wastewater compared with pre-irrigation. Gharaibeh et al. (2007) also found that the field capacity increased in the top and sub-layers of the soil irrigated with wastewater according to the initial values. Soil organic matter enhances useful water retention for plants due to the improvement it makes in porosity and aggregation (Huntington, 2005). As a result, observation of higher water retention at the field capacity in the soil after the experiment in our study could be explained by higher OM content compared with pre-irrigation practices (Tables 2 and 5). Reichert et al. (2009) confirmed that organic matter increased water retention at the field capacity.

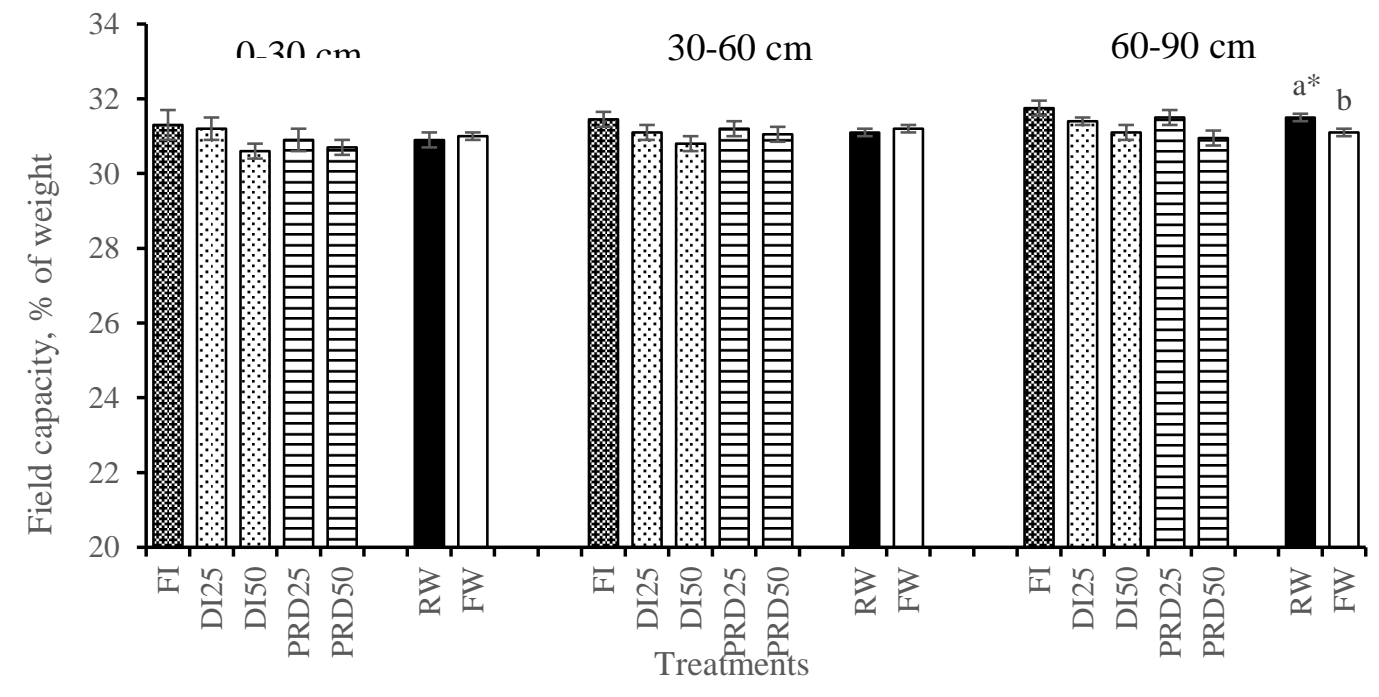

Fig. 5 The field capacity values as two-year average in three soil layers in different irrigation practices and water types. The mean values marked with different letters are significantly different $(*: \mathrm{P}<0.05)$. Explanations of the abbreviations are as shown in Fig 1 


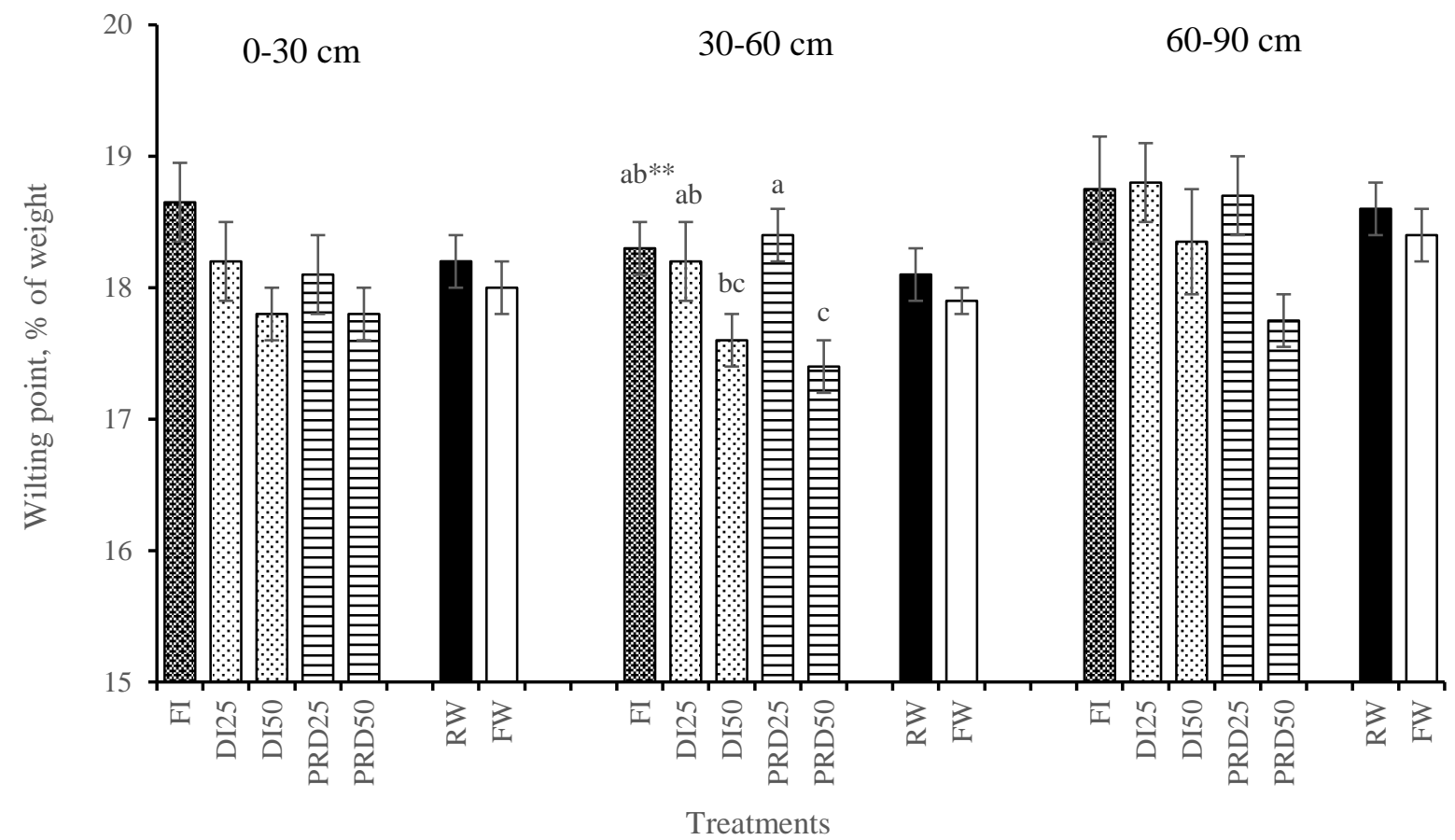

Fig. 6 The wilting point values as two-year average in three soil layers in different irrigation practices and water types. The mean values marked with different letters are significantly different $(* *$ : $\mathrm{P}<0.01)$. Explanations of the abbreviations are as shown in Fig 1

The RW and FW treatments had a similar effect on the soil moisture retained at the wilting point in three soil layers (Fig. 6). The highest values were observed in the bottom soil layer in both water sources. After two experimental years, wilting point values in the surface soil layer were higher than the initial values in Table 1 by 5.8 and $4.7 \%$ in RW and FW treatments, respectively. Although the irrigation practices had nosignificant effect on wilting point in $0-30 \mathrm{~cm}$ and $60-90 \mathrm{~cm}$ soil layers, the DI50 and PRD50 practices in 30-60 cm soil layer provided lower values compared with the DI25, PRD25, and FI practices (Fig. 6). Moreover, these values were lower than the initial values (Table 2). Compared with pre-planting, the decreases were $2.8 \%$ for DI50 and 3.9\% for PRD50 practice considering the average values for both water types. The DI and PRD practices with 50\% water shortage showed lower values in the other soil layers as well. This phenomenon could be explained by the fact that soil microporosity may be reduced under lesser soil wetting (Tunc and Sahin, 2015). Generally, RW treatments in all practices caused higher wilting point values compared with FW treatment. Narrowing in soil pores because of the accumulation of both the suspended solids in the RW and the soil particles dispersed due to the higher ESP in the RW irrigation may be the reasons for this finding. Similarly, Al-Othman (2009) determined that the wilting point significantly increased in a loamy sand soil irrigated with treated domestic wastewater.

Available water contents calculated from the differences in water contents between field capacity and wilting point in three soil layers were not affected by different water types and practices (Fig. 7). The values did not change with soil depth either. Soil total porosity and pore size distribution are the important factors that affect the water retention. Our results showed that total porosity values were not affected by different water qualities and practices (Fig 3). Therefore, this confirmed the non-significant changes in available water content. Available water content in 0-30 and 30-60 cm soil layers under different water types and practices were higher than the initial values (Table 2). The RW and FW treatments increased available water content by 12.9 and $15.0 \%$ in $0-30 \mathrm{~cm}$ soil layer, and by 5.0 and 
$7.3 \%$ in $30-60 \mathrm{~cm}$ soil layer, respectively. When compared with the pre-planting values, the available water content under the FI, DI25, PRD25, DI50, and PRD50 practices in surface soil layer were higher by $12.5,16.6,13.8,13.2$, and $13.2 \%$, respectively considering the average values for two water types. The increases in 30-60 cm soil layer were also by 7.1, 4.4, 7.3, 3.5, and 9.0\%, respectively. Gharaibeh et al. (2007) determined higher available water contents than initial values in top and subsoil layers of the soil irrigated with wastewater. It could be expressed that considering the pre-planting OM values in our study, the increase of the OM content after the experiments resulted in an increase of available water content. Reichert et al. (2009) declared that the available water content had a positive correlation with the soil organic matter. Biswas et al., (2017) and Rawls et al. (2003) observed that soil organic matter increased water retention.

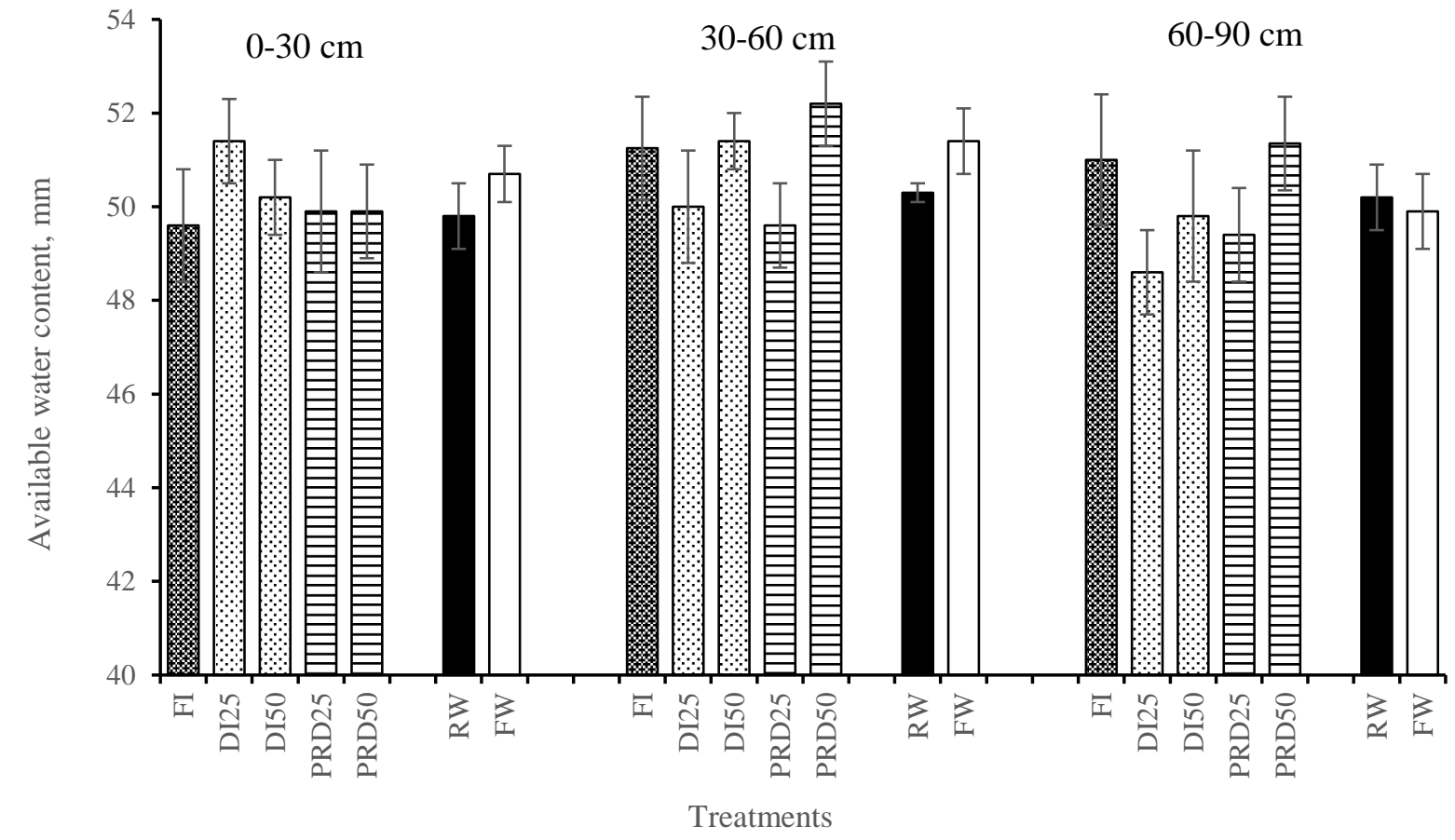

Fig. 7 The available water content values as two-year average in three soil layers in different irrigation practices and water types. Explanations of the abbreviations are as shown in Fig 1

\section{Infiltration}

The changes in infiltration rate expressed with equations based on the Kostiakov model were statistically similar in both experiment years. Considering the two-year average values, the infiltration rates observed in the RW and FW treatments decreased throughout the measuring time of $420 \mathrm{~min}$., and while the PRD50 practices had higher values, the least values were obtained in the FI practice (Fig. 8). The fact that no difference in mean infiltration rates at the end of measurement time of 420 minutes was observed under any application indicated that neither the water qualities nor the irrigation practices had an effect on the mean infiltration rates (Fig. 9). The stable infiltration rate values in the RW treatment at the end of 420 minutes measurement were significantly lower than the values of FW treatment (Fig. 9). Decrease level was $6 \%$ compared with the FW value. Considering the pre-planting values of the first experiment year $\left(22.3 \mathrm{~mm} \mathrm{~h}^{-1}\right)$, stable infiltration rates that were measured under the RW and FW treatments after the experiments reduced by 8.5 and $2.8 \%$, respectively. However, mean infiltration rates at the end of the experiment except for the treatment that was fully irrigated with the RW were higher than the initial value $\left(46.9 \mathrm{~mm} \mathrm{~h}^{-1}\right)$. The highest increase rate was determined to be $13.7 \%$ in the PRD50 practice under both of the water sources (Fig. 9). Pore size distribution affects the water infiltration and percolation in the soil. Hence, relatively high infiltration rates in the PRD50 could be explained by a partial increase 
in macroporosity due to the wetting-drying process in the PRD practices that may affect macroporosity (Bodner at al., 2013). Lado and Ben-Hur (2009) pointed out that both wastewater and soil properties have a combined impact on soil hydraulic properties. In our study, the soil ESP values in the RW treatment in surface soil layers were higher than the values in the FW (Table 5). Moreover, the wastewater used in the present study included TSS and $\mathrm{Na}$ at higher concentrations compared with FW (Table 3). The accumulation of dispersed clay and suspended solid particles in the soil pores due to the effects of these factors could decrease stable infiltration rate under wastewater irrigation. Adhikari et al. (2012) reported that water movement in soil may decrease due to clay dispersion and suspended solid accumulation in the soil pores in the saline/sodic wastewater treatments. Similarly, Gharaibeh et al. (2007) expressed that higher Na caused dispersion and so water conductivity was negatively affected, and they observed lower infiltration rates in soils irrigated with wastewater for two to five years. Mollahoseini (2013) found that saturated water movement in upper soil layers decreased significantly due to the filling of suspended particles in wastewater within the soil porosity. Assouline and Narkis (2011) determined lesser infiltration rates in the long-term wastewater-irrigated soils compared with freshwater. Bedbabis et al. (2014) observed significant decreases in infiltration rate under the wastewater treatment conditions at the end of four years. Alrajhi et al. (2017) found that the different irrigation practices (FI, DI25, DI50, PRD25, and PRD50) and water sources did not cause significant differences in the water conductivity.
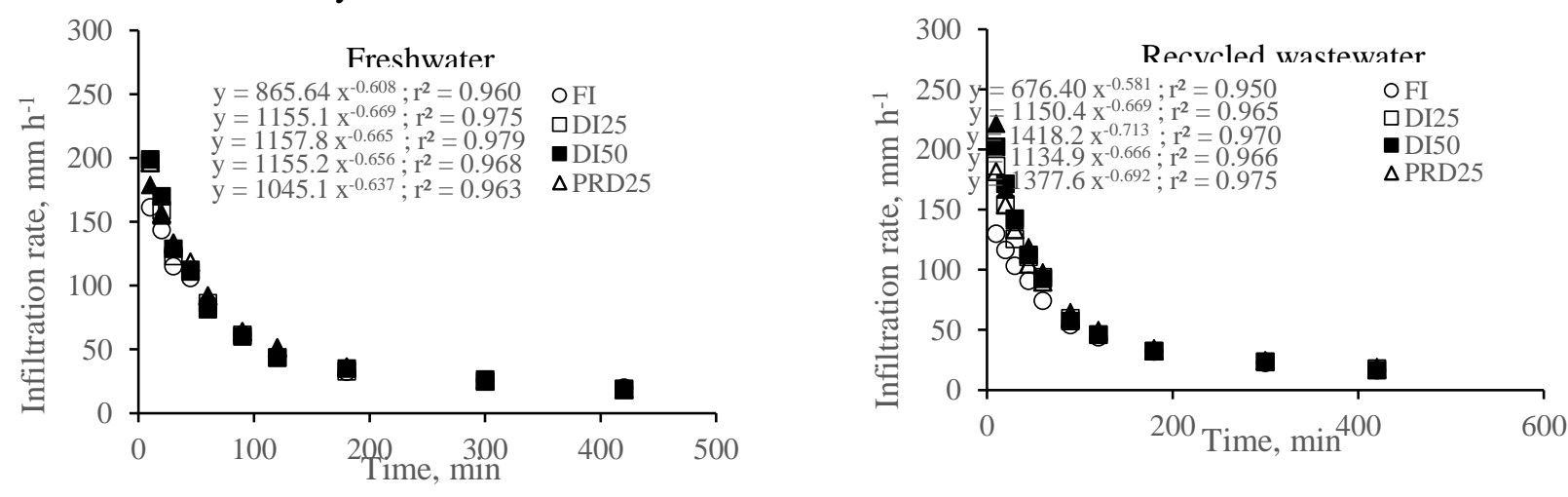

Fig. 8 The infiltration rate values versus time as two-year average in different irrigation practices and water types. Explanations of the abbreviations are as shown in Fig 1

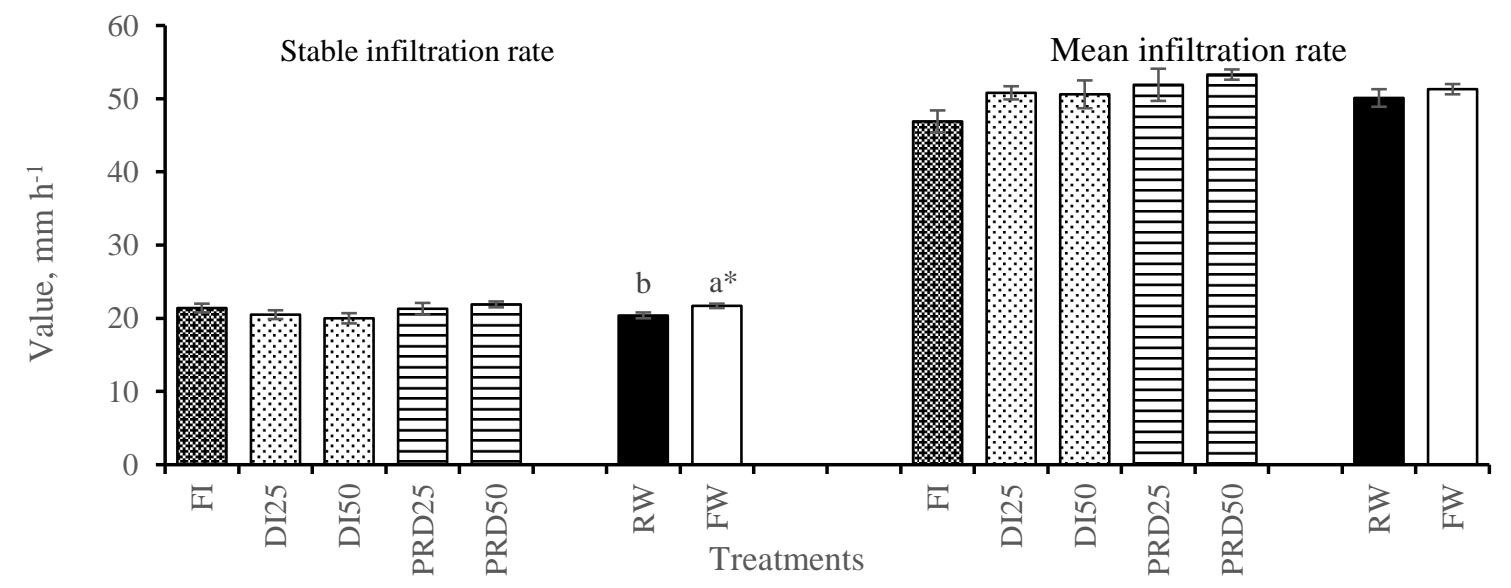

Fig. 9 The stable and mean infiltration rate values as two-year average in different irrigation practices and water types. The mean values marked with different letters are significantly different $(*: \mathrm{P}<0.05)$. Explanations of the abbreviations are as shown in Fig 1 


\section{Conclusions}

In this study conducted in Bingöl province conditions, it was seen that treated wastewater caused changes in physical, chemical and hydraulic properties of soils, but these changes were at levels that could be controlled and safe in the short term.

The findings showed that different water types and irrigation practices had slight effects on soil physical and hydraulic properties. Wet aggregate stability was highly improved in the plots fully irrigated with recycled wastewater.

It is concluded that soil physical and hydraulic properties with the PRD practices under the RW treatment were preserved and even slightly improved compared with the initial values.

In this study carried out for two years, where pressure on clean water resources is increasing for supply the irrigation water in today's conditions that it is concluded that treated wastewater can be used to irrigate tomato plant.

\section{References}

Abedi-Koupai, J., Mostafazadeh-Fard, B., Afyuni, M., Bagheri, M.R. (2006). Effect of treated wastewater on soil chemical and physical properties in an arid region. Plant Soil Environ. 52, 335-344.

Adhikari, P., Shukla, M.K., Mexal, J.G. (2012). Spatial variability of hydraulic conductivity and sodium content of desert soils: implications for management of irrigation using treated wastewater. Trans. ASABE. 55, 17111721.

Aiello, R., Cirelli, G.L., Consoli, S. (2007). Effects of reclaimed wastewater irrigation on soil and tomato fruits: A case study in Sicily (Italy). Agric. Water Manage. 93, 65-72.

Al-Omron A.M.,, El-Maghraby, S.E., Nadeem, M.E.A., El-Eter, A.M., Al-Mohani, H. (2012). Long term effect of irrigation with the treated sewage effluent on some soil properties of Al-Hassa Governorate, Saudi Arabia. J. Saudi Soc. Agr. Sci. 11, 15-18.

Al-Othman, A.A. (2009). Effect of treated domestic wastewater on physical and chemical characteristics of soils. J. App. Sci. 9, 901-908.

Alrajhi, A., Beecham, S., Bolan, N.S., Hassanli, A. (2015). Evaluation of soil chemical properties irrigated with recycled wastewater under partial root-zone drying irrigation for sustainable tomato production. Agric. Water Manage. 161, 127-135.

Alrajhi, A., Beecham, S., Hassanli, A. (2017). Effects of partial root-zone drying irrigation and water quality on soil physical and chemical properties. Agric. Water Manage. 182, 117-125.

Assouline, S., Narkis K. (2011). Effects of long-term irrigation with treated wastewater on the hydraulic properties of a clayey soil. Water Res. Res. 47, W08530.

Assouline, S., Narkis, K., Gherabli, R., Sposito, G. (2016). Combined effect of sodicity and organic matter on soil properties under long-term irrigation with treated wastewater. Vadose Zone J. 15(4).

Ayers, R.S., Westcot. D.W. (1985). Water Quality for Agriculture. FAO Irrigation and Drainage Paper 29, Rome. Bedbabis, S., Rouina, B.B., Boukhris, M., Ferrara, G. (2014). Effect of irrigation with treated wastewater on soil chemical properties and infiltration rate. J. Environ. Manag. 133, 45-50.

Beigi, H.H., Banitalebi, G. (2013). The effect of long-term application of municipal wastewater on soil physical quality indices: a case study in the Taqanak farms, Shahrekord. J. Water Soil (Agr.Sci. Technol.) 27, 1046-1056.

Biswas, S.K., Mojid, M.A., Wyseure, G.C.L. (2017). Physicochemical properties of soil under wheat cultivation by irrigation with municipal wastewater in Bangladesh. Comm. Soil Sci. Plant Anal. 48,1-10. 
Blake, G.R., Hartge, K.H. (1986a). Bulk density,.in: Klute, A. (Ed.), Methods of Soil Analysis, part 1, Physical and Mineralogical Methods, $2^{\text {nd }}$ ed. Agronomy Monograph 9, American Society of Agronomy Inc., Madison, WI, pp. 363-375.

Blake, G.R., Hartge, K.H. (1986b). Particle density, in: Klute, A. (Ed.), Methods of Soil Analysis, part 1: Physical and Mineralogical Methods, $2^{\text {nd }}$ ed. Agronomy Monograph 9, American Society of Agronomy Inc., Madison, WI, pp. 377-381.

Bodner, G., Scholl, P., Kaul, H.P. (2013). Field quantification of wetting-drying cycles to predict temporal changes of soil pore size distribution. Soil Tillage Res. 133, 1-9.

Bronick, C.J., Lal, R. (2005). Soil structure and management: a review. Geoderma. 124, 3-22.

Cassel, D.K., Nielsen, D.R. (1986). Fields capacity and available water capacity, in: Klute, A. (Ed.), Methods of Soil Analysis, part 1, Physical and Mineralogical Methods, $2^{\text {nd }}$ ed. Agronomy Monograph 9, American Society of Agronomy Inc., Madison, WI, pp. 901-926.

Castro, E., Mañas, M.P., Heras, J.D.L. (2011). Effects of wastewater irrigation on soil properties and turfgrass growth. Water Sci. Technol. 63.8, 1678-1688.

Coppola, A., Santini, A., Botti, P.,Vacca, S., Comegna, V., Severino, G. (2004). Methodological approach for evaluating the response of soil hydrological behavior to irrigation with treated municipal wastewater. J. Hydrol. 292, 114-134.

Danielson, R.E., Sutherland, P.L. (1986). Porosity, in: Klute, A. (Ed.), Methods of Soil Analysis, part 1: Physical and Mineralogical Methods, $2^{\text {nd }}$ ed. Agronomy Monograph 9, American Society of Agronomy Inc., Madison, WI, pp. 443-460.

Darvishi, H.H. (2014). Field capacity changes by irrigation with domestic wastewater. J. Biodiver. Environ. Sci. 5, 13-17.

Durán-Álvarez, J.C., Jiménez-Cisneros, B. (2014). Beneficial and negative impacts on soil by the reuse of treated/untreated municipal wastewater for agricultural irrigation - a review of the current knowledge and future perspectives, in: Hernandez-Soriano, M.C. (ed.), Environmental Risk Assessment of Soil Contamination. InTech, pp. 137-197.

García-Orenes, F., Mataix-Solera, C.G.J., Navarro-Pedreño, J., Gómez, I., Mataix-Beneyto, J. (2005). Factors controlling the aggregate stability and bulk density in two different degraded soils amended with biosolids. Soil Tillage Res. 82, 65-76.

Gee, G.W., and Bauder, J.W. (1986). Particle-size analysis, in: Klute, A. (Ed.), Methods of Soil Analysis, part 1, Physical and Mineralogical Methods, $2^{\text {nd }}$ edn. Agronomy Monograph 9, American Society of Agronomy Inc., Madison, WI, pp. 383-411.

Gharaibeh, M.A., Eltaif, N.I., Al-Abdullah, B. (2007). Impact of field application of treated wastewater on hydraulic properties of vertisols. Water Air Soil Pollut. 184, 347-353.

Gonçalves, R.A.B., Gloaguen, T.V., Folegatti, M.V., Libardi, P.L., Lucas, Y., Montes, C.R. (2010). Pore size distribution in soils irrigated with sodic water and wastewater. R. Bras. Ci. Solo. 34, 701-707.

Gould, I.J., Quinton, J.N., Weigelt, A., De Deyn, G.B., Bardgett, R.D. (2016). Plant diversity and root traits benefit physical properties key to soil function in grasslands. Ecol. Letters. 19, 1140-1149.

Gransee, A., Führs, H. (2013). Magnesium mobility in soils as a challenge for soil and plant analysis, magnesium fertilization and root uptake under adverse growth conditions. Plant Soil. 368, 5-21.

Haghnazari, F., Shahgholi, H., Feizi, M. (2015). Factors affecting the infiltration of agricultural soils: review. Int. J. Agron. Agr. Res. 6, 21-35. 
Huntington, T.G. (2005). Available water capacity and soil organic matter, in: Lal. R. (Ed.), Encyclopedia of Soil Science, $2^{\text {nd }}$ ed. CRC Press, pp. 139-143.

Kanber, R., Ünlü, M. (2010). Water and Soil Salinity in Agriculture. Çukurova University, Agricultural Faculty Publication No. 281, Adana. (In Turkish)

Kemper, W.D., Rosenau, R.C. (1986). Aggregate stability and size distribution, in: Klute, A. (Ed.), Methods of Soil Analysis, part 1, Physical and Mineralogical Methods, $2^{\text {nd }}$ ed. Agronomy Monograph 9, American Society of Agronomy Inc., Madison, WI, pp. 425-442.

Kesici, T. ve Kocabaş, Z., 2007. Biyoistatistik. Ankara Üniversitesi Eczacılık Fakültesi Biyoistatistik Yayın No: 94. Ankara.

Khan, A., Javid, S., Muhmood, A., Mjeed, T., Niaz, A., Majeed, A. (2013). Heavy metal status of soil and vegetables grown on peri-urban area of Lahore district. Soil Environ. 32, 49-54.

Khaskhoussy, K., Kahlaoui, B., Nefzi, B.M., Jozdan, O., Dakheel, A., Hachicha, M. (2015). Effect of treated wastewater irrigation on heavy metals distribution in a Tunisian soil. Eng. Tech.Appl. Sci. Res. 5, 805-810.

Kiziloglu, F.M., Turan, M., Sahin, U., Angin, I., Anapali, O., Okuroglu, M. (2007). Effects of wastewater irrigation on soil and cabbage-plant (brassica olerecea var. capitate cv. yalova-1) chemical properties. J. Plant Nutr. Soil Sci. 170, 166-172.

Kiziloglu, F.M., Turan, M., Sahin, U., Kuslu, Y., Dursun, A. (2008). Effects of untreated and treated wastewater irrigation on some chemical properties of cauliflower (Brassica olerecea L. var. botrytis) and red cabbage (Brassica olerecea L. var. rubra) grown on calcareous soil in Turkey. Agric. Water Manage. 95, 716-724.

Kottek, M., Grieser, J., Beck, C., Rudolf, B., Rubel, F. (2006). World Map of the Köppen-Geiger climate classification updated. Meteorol. Z. 15, 259-263.

Lado, M., Ben-Hur, M. (2009). Treated domestic sewage irrigation effects on soil hydraulic properties in arid and semiarid zones: A review. Soil Tillage Res. 106, 152-163.

Magesan, G.N. (2001). Changes in soil physical properties after irrigation of two forested soils with municipal wastewater. New Zeal. J. Forest. Sci. 31, 188-195.

McLean, E.O. (1982). Soil pH and lime requirement, in: Page, A.L., Miller, R.H., Keeney, D.R. (Eds.), Methods of Soil Analysis, part 2, Chemical and Microbiological Properties, $2^{\text {nd }}$ ed. Agronomy Monograph 9, American Society of Agronomy Inc., Madison, WI, pp. 199-224.

Mojid, M.A., Wyseure, G.C.L. (2013). Implications of municipal wastewater irrigation on soil health from a study in Bangladesh. Soil Use Manag. 29, 384-396.

Mojiri, A. (2011). Effects of municipal wastewater on physical and chemical properties of saline soil. J. Biol. Environ. Sci. 5, 71-76.

Mollahoseini, H. (2013). Long term effects of municipal wastewater irrigation on some properties of a semiarid region soil of Iran. Int. J. Agron. Plant Product. 4, 1023-1028.

Muyen, Z., Moore, G.A., Wrigley, R.J. (2011). Soil salinity and sodicity effects of wastewater irrigation in South East Australia. Agric. Water Manage. 99, 33-41.

Nadav, I., Tarchitzky, J., Chen, Y. (2013). Water repellency induced by organic matter (OM) in treated wastewater (TWW) infiltration ponds and irrigation, in: Xu, J., Wu, J., He, Y. (Eds.), Functions of Natural Organic Matter in Changing Environment. Springer, Netherlands, pp. 883-887.

Rawls, W.J., Pachepsky, Y.A., Ritchie, J.C., Sobecki, T.M., Bloodworth, H. (2003). Effect of soil organic carbon on soil water retention. Geoderma. 116, 61-76.

Reichert, J.M., Albuquerque, J.A., Kaiser, D.R., Reinert, D.J., Urach, F.L., Carlesso, R. (2009). Estimation of water retention and availability in soils of Rio Grande do Sul. R. Bras. Ci. Solo. 33, 1547-1560. 
Rühlmann, J., Körschens, M., Graefe, J. (2006). A new approach to calculate the particle density of soils considering properties of the soil organic matter and the mineral matrix. Geoderma. 130, 272-283.

Sahin, U., Eroğlu, S., Sahin, F. (2011). Microbial application with gypsum increases the saturated hydraulic conductivity of saline-sodic soils. Appl. Soil Ecol. 48, 247-250.

SAS, (2000). Software for Release 8.1. Statistical Analysis System Institute, Cary, NC, USA.

Schacht, K., Marschner, B. (2015). Treated wastewater irrigation effects on soil hydraulic conductivity and aggregate stability of loamy soils in Israel. J. Hydrol. Hydromech. 63, 47-54.

Tayel, M.Y., El-Hady, M.A., Eldardiry, E.I. (2010). Soil structure affected by some soil charactersitics. AmericanEurasian J. Agric. Environ. Sci. 7, 705-712.

The Official Gazette, (2010). Regulation on Use in Soil of Domestic and Urban Sewage Sludge in Turkey. The Official Gazette No: 27661, Ankara. (In Turkish)

Tunc, T., Sahin, U. (2015). The changes in the physical and hydraulic properties of a loamy soil under irrigation with simpler-reclaimed wastewaters. Agric. Water Manage. 158, 213-224.

Tunc, T., U. Sahin, (2016). Red cabbage yield, heavy metal content, water use and soil chemical characteristics under wastewater irrigation. Environ. Sci. Pollut. Res. 23, 6264-6276.

Vogeler, I. (2009). Effect of long-term wastewater application on physical soil properties. Water Air Soil Pollut. 196, 385-392.

Wang, B.T, Zhang, C.H., Qiu, X.L., Ji, E.Y, Zhang, W.H. (2015). Research on wetting-drying cycles' effect on the physical and mechanical properties of expansive soil improved by OTAC-KCl. Advan. Material. Sci. Eng. 304276, 1-7.

Wang, J.F., Wang, G.X., Wanyan, H. (2007). Treated wastewater irrigation effect on soil, crop and environment: wastewater recycling in the loess area of China. J. Environ. Sci. 19, 1093-1099.

WPCR, (2008). Water Pollution Control Regulation. The Official Gazette of the Turkish Republic No 26786, Ankara, Turkey.

Submitted: 02-07-2019 Accepted: 22-10-2019 